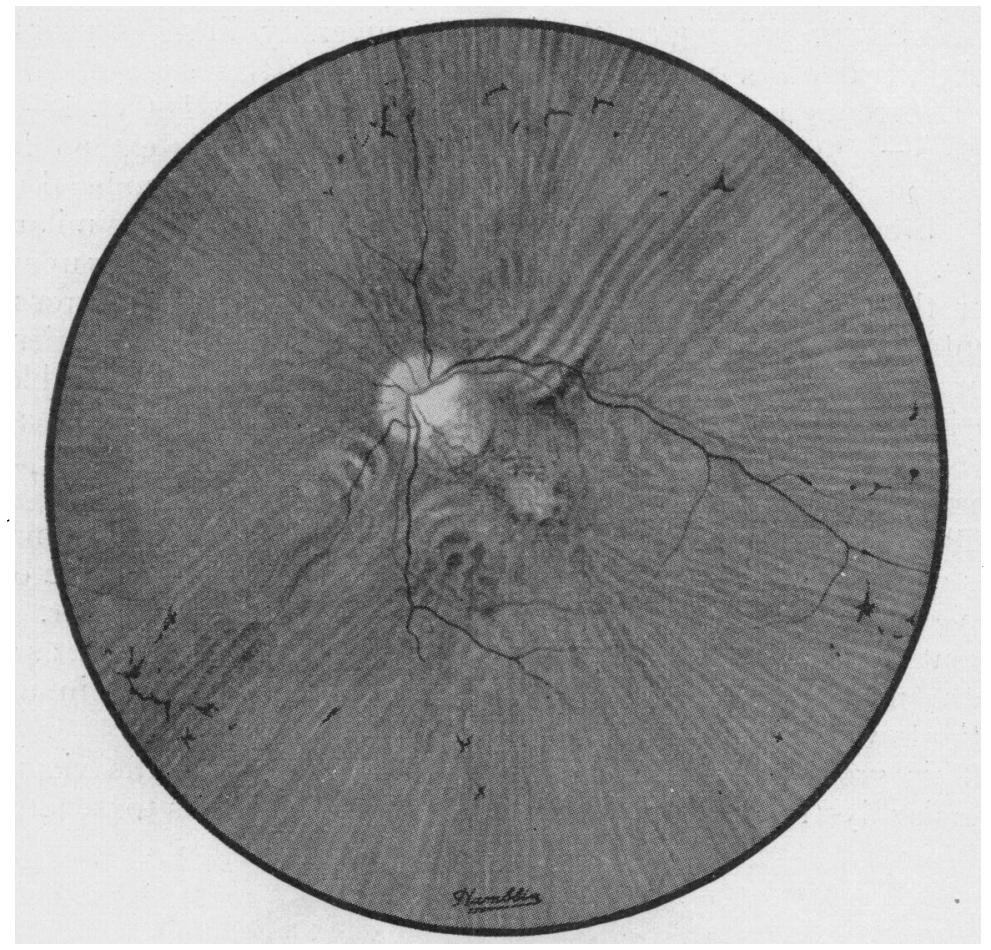

FIG. 2.

retinal dystrophy of which retinitis pigmentosa is the best known type. The various clinical types of retinal dystrophy are not rigid entities, but probably localised expressions of one fundamental disturbance.

I am indebted to Mr. F. A. Williamson-Noble for kindly referring this family to me.

\title{
A FIFTEENTH CENTURY ENGLISH TRANSLATION OF JOHN OF ARDERNE'S de Cura Oculorum
}

BY

$$
\begin{aligned}
& \text { R. R. JAMES } \\
& \text { WOODBRIDGE }
\end{aligned}
$$

JoHn of Arderne was the first of a long line of celebrated English surgeons. He was born in 1307 and was in practice at Newarkon-Trent from 1349 to 1370 . In the latter year he moved to London and in 1377 he wrote his booklet which forms the subject of this 
paper. We do not know the date of his death, nor do we know where he learnt his art. In one of his writings he describes himself as " chirurgus inter medicos," and in another as " cirurgicorum minimus"; but he was evidently in extensive practice and his writings cover a very large field. Perhaps his best work was on fistula-in-ano, piles and rectal cancer. This displays great powers of observation and is well documented with case records. It is decidedly original. The same cannot be said of his treatise on the cure of the eyes; it is for the most part a compilation from the work of others, notably Lanfranc. Ophthalmologically it is worthless, but not without interest.

We know of two early manuscripts of this booklet. The first is in Latin and is in the Sloane collection at the British Museum (Sloane Ms. 75, fol. 145). It is considered as belonging to the early part of the fifteenth century. The second is a fifteenth century Ms. in English at Emmanuel College, Cambridge (Ms. Western, 69, fol. 65). The latter was copied by Sir D'Arcy Power and was alluded to by him in a paper on Arderne's works read at the Seventeenth International Congress of Medicine in London in August 1913. This copy is now in the library of the Royal College of Surgeons of England.

Although the two texts agree in their sense to a large extent they are by no means the same. The Latin text gives us Arderne's own statement that he wrote the treatise in the year 1377 when he was seventy years of age ; this is not found in the English Ms., nor is the arrangement of the subject matter quite similar.

A brief abstract of the contents of the Latin text was given in my " Studies in the History of Ophthalmology in England prior to 1800 ," and may be epitomised at this point with advantage.

The title is de cura oculorum. In the first place is given the method of preparation of a collyrium for sick eyes due either to injury or flux of humours. Then follows the account of an emplastrum; the contents of the latter are the white of a raw egg well beaten up, to which is added a half part of rose water and a like amount of woman's milk with the weight of a penny or a halfpenny of crocus. Next there is a paragraph on swelling and discharge. Arderne makes a great point of purgation by means of " the pills without which I would not like to be." An apple poultice and the bramble collyrium called redebrerecropys, epatica and oil of roses are recommended; and then comes a long paragraph on the excellencies of tutty. This is followed by the views of John of Damascus on hot and cold causes of disease and the good results obtained by means of general treatment with the ierapige of Galen, both of which occur in the English Ms. Lippitudo is next dealt with and then Arderne wanders off into more general matters, such as laxatives, an acid drink, alleviation of piles and a trochiscus for coughs. 
The English Ms. has no title. At the bottom of a page which deals with the treatment of orchitis Arderne suddenly bursts into a description of the use of tutty in sore eyes. In printing the Ms. I have tried to keep as close to the original as possible but an exact reproduction would have necessitated the use of a special fount of type. The writer has no method in his spelling and we find the same word spelt in a variety of ways in different parts of the Ms., but this is of course common in all such early manuscripts. The writer's "yzene, yze, yene" all mean eyes. "Th" at the beginning of a word such as " the " is rendered by a sign which looks like a cross between a capital "D" and a capital "V." After much cogitation I have decided in most instances to print it " D" "; " th " in the middle of a word is printed " $d$," as "fader" for "father"; "th" at the end of a word I have printed "th:"" "In de weche", will be easily recognised as "in the which," but " dus" for " thus" looks odd and I hope that readers will be able to make out the sense. The ampersand is given as in the original. The letter " $\mathrm{g}$ " is often written " $\mathrm{y}$," e.g., " ey " or " eye " means " egg." You find the same spelling in Chaucer.

The transcript of the English Ms. is as follows:-

Thuthia is founden at de potekaryes \& a pounde ther-of is worth XII d. De thennest platys of hem schulbe chosene to cure with de yzene, \& they comen from beyende de see. It is a grete medycine for de yzene whanne it is made redy as scheweth after. And it schalbe made redy in dis wyse. Tuthia schalbe putte in a schelle or in a litill erdene potte \& sette in a strong fyre be de space of ane oure une-to de tyme it will be glowinge hote, $\&$ dane it schalbe taken out \& qweynt in de juse of ffenell or in whyte wyne, or in de uryne of a mane-chylde dat is a virgyne, $\&$ whanne it is colde it schalbe putte in-to de fyre avene $\&$ made hote as it was to-fore, and afterwardes qwenchyd ayene in de same liquor.

And so it schalbe done IX tymys atte de leeste. Ind after de laste combustyone it schall kele by it-selffe without ony more qwenchynge \& whanne nede is it schalbe grounden small uppone a stone \& putte in-to de yze. Dis pouder conforteth de syghte with wypinge and dryinge and doeth awey de sorowe of de yzene ffor by his coldnesse he taketh awey de flowynge mater and with his drynesse de weche is with-outen fretynge he dryeth up de superfluites dat be gaderyd togydere in de veynys of de yzene.

And de strenger werker of de II ys de wasscher, for thorough wasschynge de erdely partys ben putte awey, \& so be de dryere and be de wasschere de helde* of de yzene ben kept.

De poudir of thuthia bounden in a small cloth $\&$ wele sodene in wyne in manere of a colerye $\&$ droppyd in-to de yzene delayeth

${ }^{*}$ helde $=$ health. 
de teerys $\&$ de rednesse $\&$ claryfieth de syghte. Note. Also thuthia wasschen as it is aforseyd and small poudryd and reffreschyde with de pouder of sugre evene medlyd togydere fretyth awey de webbe or de cloth in de yzene \& claryfieth de syghte, it constreyneth de teerys \& maketh small de swellynges of de yze-lyddys, \& destroyeth de rednesse $\&$ de yechynge it delayeth \& maketh de yzene opene \& large \& conforteth \& preservyth de syghte. Also a droppe of bawme droppyd II or III in de yzene of hem that haven spottys or webbys clensyth wele de yzene \& scharpeth strongley de syghte \& by his naturall vertyw he strengtheth \& conforteth per certo. ffor de ruborous \& brennynge of de yzene $\&$ for terys \& to conserve \& fortyfye de syghte, Recipe. Tuthie small poudryd $\&$ medle it with de lyquour in de weche it was last qwenyte after de combustyone $\&$ yf it be foryeten in weche lyquour it was qweynt, danne medle it with de uryne of a masculyne chylde dat is a mayde or with whyte wyne \& make it not to thenne, but as it may cleve to de sydes of ane holowgh basyne dat is fayre and clene de weche schalbe anoyntyd abowte de botomme, of de tuthye medlyd with de uryne or with de whyte wynee and after de anoyntynge it schall stande stylle a whyle \& drye that it renne not awey by de sydes of de basyne, but or it be all drye.

Take de pouder de Aloes epatyke $\&$ throwe it uppone qwyke colys \& anon de basyne with Tuthye schalbe whelwyd* ther-one $\&$ so it schall lye tylle it be drye of de fume of aloes that ascendyd upp therto. And whanne it is colde take dat that clevyth to de basyne $\&$ schave it of, $\&$ yf it be nede grynde it smaller $\&$ whanne thou wolt use it. Take of thys pouder a lityll quantyte $\&$ putte it uppon de spotte of de yze \& it schall hele it $\&$ de oder forseyd syknesse of de yzene atte de beste with de softers remollytyffes furste putte.

Also for de cloowd in de yze to putte it awey withoute ony duresse \& to claryfye de yze and to hele it perfytly with dis medicine contynued de weche schalbe made thus. Recipe. of de graynes of eyrene XXX or XL \& with sugre caffatyffe bray hem in a basyne mortar in de manere of salte $\&$ afterward drye hem at de sonne and make pouder ther-of $\&$ putte ther-of in de yze $\&$ it schalle delaye de forseyd peyne.

ffor strokys of de yzene of what manere dat evere de ben with stone or staffe or harde stubbe or swerd $\dagger$ or ony lyke. The pacient schalbe holpe as sone as it may be with de cleere of ane ey or de humours be dyssolvyd in de yze wher through it myght be destroyed. And bewar dat dou putte no manere medicine to de yze whanne it is nywe hurte but de whyte of ane ey wele steryd \& dyspumyd \& with de hurdys of clene fflex \& small it schalbe putte

* Inverted. † Sword. 
uppone de yze clos. We seyne furdermore dat de cleer of ane eye (egg) doth III thynges to de yze dat is smetyne ffurst it swageth for hys softnesse, de seconde it constrayneth de wykkyd humours of de yene, de thyrde it clensyth and letteth that no superfluite of oder humours or spywme schull come to de yzene. And it is callyd cleer for it clarefyeth. And yf ther be putte to dis medicine a lityll saffrone and womans mylke it is de more perfyter, from lanfrancum. Some folysshe lechys and unkunnynge whane dey seene a mane smytene in de yze dey takene wex and comyne poudryd \& medlyd togedere \& make ane emplastre $\&$ dey leye it hote uppone de ye dat is hurtte.

And lanfrancus seyth dat yf de cote of de yze be broken it draweth outward all de substances of de yze \& so folowynge all de humours of de yze. ffor de wex hath II propirtees, it draweth $\&$ consumyth. And de comyne dyssolveth $\&$ melteth thorough his hete $\&$ moystenesse $\&$ dese III ben contrarious de weche destoyene all de substaunse of de yze, dat is to seye, dyssolvynge drawynge $\&$ consumynge. And yf de cote of de ye be not brokene, thanne de forseyde emplastre dat is dere causeth de spirytes $\&$ de humours to have grete sorowe \& prykkynge abowte de yze \& so de yze is alwey appeyryd tyll it is wastyd with all de substaunse. And therfor in what wyse dat ever de yze be smetyne with-inne or with-oute de medicine schalbe alwey as it is aforseyd with de cleere of ane eye. ffor all that is lyke encresyth \& norysscheth hys lyknesse. And for dat de ye is cold of complexione he dyssolveth not de humours of his norysschenge for de stroke dat he sustenyth from lanfrancum $\&$ it is to wete dat many have loste here yzene thorough ane emplastre made of wormode \& olibanum \& oder hote thynges dyssolvynge, from lanfrancum.

Ther-for be-war of de forseyde thynges de weche hurtyne. After some auctours de yelke of ane ey with de oyle of rosys putte uppone de yze dat is smeten or kutte with irene abateth de ache. Also yf de ye be smeten $\&$ almoste throwen oute and be blody Recipe de juse of agrimonye with de whyte of ane ey wele beten $\&$ despumyd $\&$ medle hem togedyre $\&$ with hurdys ley it ther-one $\&$ it schalbe wele helyd per certo. And yf de cote of de ye be broke of ony stroke, thenne this medicine schalbe putte withinne de ye, de weche is callyd virtus a deo datur, dat is to seye, a vertyw yoven of god \& founden be de seyd lanfrancum.

And for de grete vertyw dat it hath in werkynge it is callyd so to fore alle oder medicines. Recipe nywe leyd eyrene of whyte hennys \& drawe oute of heme alle de streyns as many as thou mayste fynde $\&$ thane putte hem in a brasyne mortare $\&$ grynde heme tyll dey be made in de manere of ane oynement $\&$ thanne putte it in a glasse, \& whanne dou schalte use it, putte therof in de yze a lityll II in de day tylle dat de cote be savyd \& hole 
thorough here savyour, de weche Johannicus calleth conninctyffe $i^{*}$ joynynge togedyre or helynge.

This medicine helyth de cote $\&$ clensyth de yze of spottys \& blemyssches yf it be done or de ye putryfye i. rote.

This reede colerye helyth alle de rubour of de yzene de weche is made, de cunis rubi, $i^{*}$ redberycroppys.

They schulbe stampyd in de manere of salt $\&$ sodene in whyte wyne to de myddell dele \& afterward it schalbe clensyd \& therof ther schalbe putte in de yze I drope or II it delayeth de rubour \& de ycchynge of de yelyddys, but de veyne of de fforhede schall furste be kutte or de medicine be putte ther-too.

Take de croppes of de ellertre or hyllertre \& stampen hem and tempre hem with de whyte of ane ey $\&$ leye it one hurdys $\&$ putte it to de ye and yf ther be putte to dis medicine saffrone it is moche de bettere, it stauncheth de sorowe of de yene of what cause that evere it be. Also aloes soden in whyte wyne \& clensyd \& with a penne droppyd in-to de ye is ane hygh remedye ayenst de ycchynge of de yene. And to this seyd medicine yf ther be putte ther-to de roote of lylye wele soden undir hote asschene, it heleth de syknesse.

Ayenste de overcomynge \& swellynge of de broowys \& for cloowdynesse of de yene ffurste ther schalbe made a purgacione with pellettes withoute de weche $I$ wole not that it be done.

This emplastre furste abateth de swellynge of de ye. de seconde it gadereth to hys place that is nedfull, de IIIde it swageth de sorowe $\&$ rekevereth de syghte from lanfrancum.

The manere of purgynge with de forseyd pellettys is dis. or de pacient be purgyd he schalbe dyetyd at de leest III dayes tofore with duretykes \& oder softe thynges, as with grywell dat is made with porke, or with woortys of malowys or borages, or Arage, \& with rere eyrene, \& every day he schalle take be de morowe fastynge VI spoonfull of de syryp of oximell, with as moche of warme water. And he schall not soowpe in dat day that he purposyth to be purgyd one de nyghte, and he schall chese hym a soowderne wynde tyme whanne de soowderne wynde is softe \& not tempestuous \& he schalbe-war dat de moone be not in signs ruminandi, dat is to seye dat it be not in Aryes, Tauro, or Capricorne. It schalbe dysposyd also yf it may be done dat de pacyent be clystered onys or he resseyve de pellettys. And whane de pacient is made redy as it is aforseyde, he schalbe purgyd ane oure after de sonne is go downe. Take of de pellettes withoute de weche I wolde not be, dat is to seye XI or XIII or XV, after de strengthe of de pacient, $\&$ de pellettes schulbe of de gretnesse of oo pese, $\&$ they schulbe yoven in rere eyrene or wounde in obeleys within wyne or ale or mede, \& without chowynge dey schulbe

"The " $\mathrm{i}$ " seems to stand here for i.e. 
swolowyd downe. And whane de pellettys ben resseyved lete de pacient do what he wole, saff he schall neyther ete ne drynke after de medicine, \& yf that he have talentte to slepe lete hym slepe a lytyll yf he may, but no full slepe, $\&$ lete hym bewar dat he swete note for so myghte de strengthe of de medicyne be consumyd.

And yf he slepe to longe he schalbe waked, \& whane de pacyent felyth hurlynge \& gurgyllynge in de wombe, de pacient schall meve hyme-selfe \& whane he seeth tyme he schall goo to seege with a basyne sette undernethe $\&$ thou schalte counte or rekene his segys \& he schall not slepe une-to de tyme dat he be fully purgyd.

And nota that de leche schalle see de syknesse of de pacyent. This purgacione dus done de pacient may slepe \& reste hym wele ynowgh, \& yf de pacient be thrystlew in de morne it is a sygne of goode purgacione.

After dis schalbe yove hyme wyne yf it may be hadde medlyd with warme water ffor that is good drynke \& holsome for de stomake \& voydeth wele de humours dat ben drawen or constreynyd be de seyde pellettes. Yf wyne may not be hade ther schalbe yove oder drynke as ale be hym-selfe or with de browes of ane henne, or of ffressch flessch \& such oder. Memorandum that I purgyd a wommane with pellettys withoute de weche I wolde not be \& I yaff hem in de month of Marche whyle de moone was in geminis \& de wynde in de sowde with de usynge only of oximelle \& I yaff here of de forseyde pellettys de weyghte dimidium ane unce abowte VIII one de clokke in de nyghte. And whane day were taken sche slept IIII owrys : after mydnyght sche begane to seege \& be VI one de clokke at morne sche hadde VII seegys $\&$ thane sche slepte ayene $\&$ aros $\&$ eet here mete in dywe tyme $\&$ was wele at ese. And it is to wete dat sche was purgyd of moche fylthy mater at de beste \& withoute grevaunce \& so de wommane was hole of a grete syknesse $\&$ of de hedache thorough usynge of de seyde medicine.

Also in the monthe folowynge whyle de mone was in cancro in all wyse as it is aforseyde, with de forseyde pellettes taken as dey were in de fyrste tyme, sche was spedde of her erande.

The mylke of a wommane or of ane asse medlyd with de yelke of a rawgh ey and with saffrone \& oyle of rosys \& putte to de ye, aswageth \& wypeth awey de fyry flewmes of de yene \& de postemys of de yene. And yf de juse of greneache be putte to de forseyd thynges, it is de more alayinge of de seyd sorowe.

Saffrone wypeth awey de fylthe of de yene $\&$ putteth awey de flowynge of humours dat rennen to de ye \& it avayleth in puttynge awey de webbe from de ye, it is resolvynge \& rypynge with de manere of styptyknesse. Also it helyth de yene dat ben enfectte with to moche blood \& de spottes of hem, dat is to seye yf it be 
of de poudre of de saffrone dat cometh from de este partys. It schalbe leyd uppone ane hote tyle to drye and with de whyte of ane ey wele beten \& dyspumyd i scomyd, it schalbe tempryd. And that is cleerest ther-of schalbe hylde in-to de ye. And whanne de ye is closyd ther schalbe putte ther-one ane emplastre of de mylke of a rawgh ey $\&$ saffrone $\&$ oyle of rosys $\&$ with de hurdys of clene fflex dat is softe it schalbe leyd uppone de ye in de manere aforseyd.

The mylke of a wommane saw swageth de sorowe of de yene, \& rypeth de mater \& clensyth \& mollyfyeth, \& it moysteth de drynesse of uvee tunice. And nota dat uvea tunica is dat dat scheweth holy or as thorough it were boryd or oyrled, de weche is schewyd in de balle of de ye.

The whyte of ane ey wele swongen and scomyd \& leyd to de ye hath III propirtees. ffurste it abateth de akynge, de seconde it constreyneth straunge humours \& kepyth de naturall humours, dat dey dyssolve not de yene, de IIIde it clensyth \& lettyth dat no superfluite of oder humours ne spume come to de yene, but only preserveth \& heleth heme.

The water of rosys chaungyth $\&$ draweth awey de in naturall hete of de yene $\&$ conforteth de brayne $\&$ multyplyeth de animall (i soul) spyrites of de brayne. The mylke of a wommans breste ofte droppyd in-to de ye rypeth $\&$ wypeth $\&$ clensyth obtalumina, dat is to sey de hote posteme of de yene $\&$ also it stauncheth de akynge from Gordon $\mathrm{ca}^{\circ}$ de eadem.

These ben de thynges dat aswagyne $\&$ meeken in de curacione of yene: de mylke of ane asse $\&$ of a wommane, de white of ane ey \& de yelke of de same, oyle rosette \& oyle of vyolette, mustilage, psillium*, lynseed \& citoniorum i cytrines. And note dat alle the thyngys dat reboune ayene or smytyne ayene de hote mater aswagen ayenward de ferventnesse ther-of. And tho dat ben smytynge ayene \& rebownynge ben these, solatrum i litill morell, popye, mandrake, de juse of popye, Alphita i barlymele, rubarbe \& such oder.

And strenger thane de rebownere ben these, and more abatynge $\&$ mekere in werkynge $\&$ ben these: Neunsar, saundrys, ceru, wylowgh, brent leed, wyld tasyll, vyne-levys, letuse, umbilicus veneris, \& actacia. And tho dat dissolven strongly in de cure of yne ben these, de juse of celidoyne, Rywe, bawme, camphour, ambre, aloe \& almanere of galle, \& alle kyndys of salt \& all oder dat have fretynge strengthe. Nota enfebelynge \& dyssolvynge ben these: de yelke of ane ey, de juse of mynte, de juse of verveyne, de levys of madir, endive, ffenell, groud-ivy, ewfrase $t$, licium, water of de vyne, hony, de blood of a culvere $\ddagger$ or of ane

\footnotetext{
* A herb known as pulicaria. † Eyebright. $\quad$ A pigeon or dove.
} 
henne checkyne $\&$ de limature of golde. These aforseyd schulbe medlyd cum repercussinis, dat is to seye with de rebownere, wheyther de syknesse be in staat or in decrese. ffor yene dat ben bloody, Take de whyte of ane ey with as moche water $\&$ putt ther-to de juse of Ache, \& whane they be wele beten $\&$ scomyd togeder anoynte de yene ther-with. ffor de same: take de juse of verveyne with de whyte of ane ey \& with hurdys leye it uppone de ye. Mordinella domestica cum flore albo i chykenmete avayleth moche stamped with de whyte of ane ey $\&$ thanne clensyd $\&$ with herdys of flex leyd ther-one, \& yf it be hyld in-to de ye it is de beste medicine for de reednesse \& swellynge ther-of $\&$ also it delayeth de spottes $\&$ de webbe in de ye, $\&$ it wole de better werke yf it be medlyd with saffrone, \& a litill water of rosys, or wommans milke yf they may be hadde. Also morginella agrestes i pympernole de weche growed in corne $\&$ in otys havyng IIII levys. It restoreth de syghte and consumyth de webbe in de ye, yf de juse ther-of be droppyd ther-inne every thyrde dey. Also pympernolle is callyd testiculus muris dat is to seye it hath testicules lyke a mows in de weche de seed lyth inne. (Here there is a drawing of pimpernel in the margin of the page,)

Artetica, dat is to seye tho that stuffene or stonyene de wytte $\&$ enducen drede ben these: de applys of mandrage hennbane, seed of popye i black \& opium, but nevertheless we use not this in de curys of yene, but only opium of de weche we have knowen de experte strength, and as we fynde is worthy to be praysed.

Ayenst de waterynge yene a trywe remedye. Take oyle of benette and anynte it abowte de templys \& it is seyd that it schalle cure de yene with-inne IIII days though de infirmitee have enduryd $\mathrm{X}$ yere. And note wele dat oyle bennette is made of nywe tyles broken in small pecys \& after they be putte in de fyre tyll dey glowen $\&$ whanne dey be glowen dey schulbe qweynt in comone oyle \& lye ther-inne all a nyght, \& after dey schulbe putte in a stilatorye $\&$ be dystylled $\&$ ther-of schalbe made ane oyle full fructuous for de seyd cause. A stryctorye ayenst de waterynge yene schalbe made dus. Recipe, de rootys of boly, sangdragone, mastix olibanum galles poudryd \& medle hym togydere with de whyte of ane ey, \& with herdys lay it uppone de forhede $\&$ de templys \& bynde it dat it falle not awey.

A precious oynement for bleryed yene and watery. Take a clene holowgh basyne $\&$ anoynt it with inne with buttere dat is not salt and afterward whelve de basyne uppone a vessell dat a mannys uryne is inne, tarte $\&$ hote $\&$ so lete it stande stylle tyll it be colde. Afterward that schalbe taken dat clevyd withinne to de basyne de weche is blewysshe of colour \& ther schalbe putte therto a litill of de grece of a caponne $\&$ des schalbe wele medlyd togydere ayene de sounne \& thanne boxe it. 
With dis oynement de yelydys schulbe anoyntyd mediocrely with a lytyll slice at eve whane he goth to bedde $\&$ bynde it with a bonde tylle one de morowe.

This oynement cureth beste above alle de medicines in de wordle de bleryed yene \& de waterynge yene as wele in crokedmen as in oder, de weche I have often tymes provyd per certo. And after Johannem Damascenum in alle de sorowe of de yene \& ayenst defawte of de syghte ffurste it behoveth dyligently to consydre wheyther it be of hote cause or of colde, $\&$ yf it be of hote cause furste de mater scalbe deffyed cum surupo acetoso III dayes or IIII. And whanne de mater is dygeste ther schall thane be yoven furste a clystere mollificatyff de mor*.

That schall devoyd all de body \& dat schall be done with $\frac{\mathrm{v}}{2} \cdot 1$. of de a lectuarye made of de juse of rosys $\&$ made scharpe with Dyagredye. And thanne thou mayst sywerly werke with diverse remedyes in de seyd places after that de semeth to spede.

In colde cause de mater also schall furste be deffyed cum oximell diuretico i squillitico \& thane ferdermore de clysterye schalbe yoven as it is aforseyde $\&$ by de morowe alle de body schalbe purgyd cum $\frac{\mathrm{v}}{2}$ from Jorapige Galet. And afterwarde he schall procede foorth sywerly to de places of remedye \& spede wele . . .

Here ends the Ms. of the cure of the eyes.

To my regret I have not been able to compare the proof with the original, and so some errors in 15th century spelling have probably crept in.

\section{ANNOTATION}

\section{Ophthalmological "Moots" in the Curriculum}

It has often struck us that more use might be made in the teaching of ophthalmology of gatherings at stated intervals, say once a week, at which a subject is propounded and discussed by the students. Such meetings used to be held, we believe, in the Mayo Clinic in general surgery, and each student in turn would propose some question for discussion. Something similar to the "Moots," those post-prandial meetings for the cracking of legal nuts, which

\footnotetext{
*The remainder of this word is lost in the binding: it is probably "owe," making "morowe."
}

† The hierapicra of Galen. 